\section{James Cook University}

Graduate Research School, Townsville, QLD 4811, Australia.

Tel: (61) 747814575

Email: GRS@jcu.edu.au

Website: www.jcu.edu.au

Contact: Manager

James Cook University prides itself on its international reputation for research and discovery and teaching that is enhanced and enlivened by that research activity.

\section{AIMS@JCU Scholarship}

Purpose: The scholarships are provided to assist with the general living costs of the candidate.

Eligibility: Both domestic and international applicants

Level of Study: Postgraduate, Research

Type: Scholarship

Value: AU\$28,092pa in US\$2,020 (living allowance paid fortnightly) + AU\$5,000pa as living allowance or project expenses

Length of Study: 4 years

Frequency: Annual

Application Procedure: www.jcu.edu.au/ data/assets/pdf file/0007/273670/2020-Scholarship-Scoring-Procedure-310519. pdf

Closing Date: 30 September

\section{For further information contact:}

Email: grsapplications@jcu.edu.au

\section{Indigenous Research Training Program Scholarship (RTPSI)}

Purpose: The scholarships are provided to assist with the general living costs of the candidate.

Eligibility: Applicants who identify as Australian Indigenous and/or Torres Strait Islander

Level of Study: Postgraduate, Research

Type: Scholarship

Value: AU $\$ 42,000$ pa in AU $\$ 2,020$ (living allowance paid fortnightly) + AU $\$ 10,000$ one off for project expenses.

Length of Study: 3.5 years

Frequency: Annual

Application Procedure: wwww.jcu.edu.au/_data/assets/ pdf_file/0007/273670/2020-Scholarship-Scoring-Procedure310519.pdf

Closing Date: 30 September

\section{For further information contact:}

Email: grsapplications@jcu.edu.au

\section{International Research Training Program Scholarship (IRTPS)}

Purpose: The scholarships are provided to assist with the general living costs of the candidate.

Eligibility: Both domestic (RTPS) and international (IRTPS) applicants

Level of Study: Postgraduate, Research

Type: Scholarship

Value: AU\$28,092pa in AU\$2,020 (living allowance paid fortnightly) + Overseas Health Cover

Length of Study: 3.5 years

Frequency: Annual 
Application Procedure: www.jcu.edu.au/_data/assets/pdf_file/ 0007/273670/2020-Scholarship-Scoring-Procedure-310519.pdf Closing Date: 30 September

\section{For further information contact:}

Email: grsapplications@jcu.edu.au

\section{James Cook University Postgraduate Research Scholarship}

Purpose: To encourage full-time postgraduate research leading to a Master's or PhD degree

Eligibility: Open to any student who has attained at least an Upper Second Class (Honours) Bachelor's Degree

Level of Study: Postgraduate

Type: Scholarship

Value: AU\$28,092 pa in AU\$2,020 (living allowance paid fortnightly)

Length of Study: 3.5 years

Frequency: Annual

Study Establishment: James Cook University

Country of Study: Australia

Application Procedure: Details of how to apply can be found here: www.jcu.edu.au/graduate-research-school/candi dates/prospective-students/how-to-apply

Additional Information: For further details visit the website www.jcu.edu.au/grs/scholarships/JCUDEV_014879.html www.jcu.edu.au/graduate-research-school/candidates/postgrad uate-research-scholarships

\section{For further information contact:}

Fax: (61) 747816204

Email: grsapplications@jcu.edu.au

\section{Master of Business Administration Programme}

Length of Study: 1 year

Application Procedure: Applicants must complete an application form supplying transcripts, a curriculum vitae, a one page essay, and referee reports

Closing Date: 15 June

\section{For further information contact:}

Faculty of Arts Commerce \& Economics MBA Programme Office of International Affairs.

Tel: $\quad$ (61) 77814407

Fax: (61) 77815988

Email: InternationalAffairs@jcu.edu.aau

\section{Sustainable Tourism CRC - Climate Change PhD Scholarship}

Eligibility: Open to the candidates who have achieved Honours 1 or equivalent

Level of Study: Postgraduate, Research

Frequency: 1

Study Establishment: 3 years

Application Procedure: AU $\$ 19,930$ per year

No. of awards given last year: James Cook University

\section{For further information contact:}

STCRC Education Program, Sustainable Tourism CRC.

Tel: $\quad$ (61) 755529063

Email: Jane@crctourism.com.au

\section{James S. McDonnell Foundation}

\section{Postdoctoral Fellowship Awards}

Subjects: Brain sciences

Purpose: The program supports scholarship and research directed toward the discovery and refinement of theoretical and mathematical tools contributing to the continued development of the study of complex, adaptive, nonlinear systems. The program's emphasis is on the development and application of the theory and tools used in the study of complex research questions and not on particular fields of research per se. JSMF is also interested in projects attempting to apply complex systems approaches to coherently articulated questions where such approaches are not yet standard but could open up new paths to progress. The JSMF Fellowship is designed to provide students with opportunities to pursue postdoctoral training that might not be otherwise readily available. The Fellowships are intended to allow students to seek postdoctoral research opportunities aligned with the student's interest and desire to obtain additional skills and experience that will further their pursuit of careers in complex systems science.

Eligibility: The JSMF Fellowship is a unique opportunity for students with an interest in and an aptitude for complexity science who are in the final stages of completing their $\mathrm{PhD}$ and looking to make a significant change in direction for their first postdoctoral fellowship (field of study, model organism, theory vs experimental, etc.) that will either be difficult or impossible without an external source of funding.

Type: Fellowship

Value: US $\$ 200,000$

Length of Study: Two to three years 
Frequency: Annual

Country of Study: Any country

Application Procedure: Complete applications must be uploaded to the JSMF website.

Closing Date: 12 June

Additional Information: www.jsmf.org/apply/fellowship/

\section{Japan Society for the Promotion of Science (JSPS)}

5-3-1 Kojimachi, Chiyoda-ku, Tokyo 102-0083, Japan.

Tel: $\quad$ (81) 32639094

Email: gaitoku@jsps.go.jp

Website: www.jsps.go.jp

The Japan Society for the Promotion of Science (JSPS) is an independent administrative institution, established for the purpose of contributing to the advancement of science in all fields of the natural and social sciences and the humanities. The JSPS plays a pivotal role in the administration of a wide spectrum of Japan's scientific and academic programmes.

\section{Japan Society for the Promotion of Science Postdoctoral Fellowships for North American and European Researchers (Short-term)}

Purpose: To assist promising and highly qualified young foreign researchers wishing to conduct research in Japan Eligibility: Be a citizen or permanent resident of an eligible country (the US, Canada, EU countries, Switzerland, Norway, and Russia). Candidates must have obtained their doctoral degree at a university outside Japan within 6 years of the date the fellowship goes into effect, or must be currently enroled in a doctoral course at a university outside Japan and scheduled to receive their $\mathrm{PhD}$ within 2 years

Level of Study: Postdoctorate, Predoctorate

Type: Fellowship

Value: Round-trip air ticket, monthly maintenance allowance of $¥ 362,000$ for $\mathrm{PhD}$ holder and $¥ 200,000$ for non- $\mathrm{PhD}$ holder, settling-in allowance of $¥ 200,000$ and overseas travel insurance, research support allowance

Length of Study: 1 year but a minimum of 1 month

Frequency: Annual

Study Establishment: Universities and research institutions Country of Study: Japan

Application Procedure: Applicants must write for details. Application must be submitted to JSPS by the host researcher in Japan
Funding: Government

Additional Information: Please see the website for further details www.jsps.go.jp/english/e-fellow/postdoctoral. html

\section{For further information contact:}

Email: agneta.granlund@stint.se

\section{Research Fellowships for Young Researchers}

Purpose: Awarded to excellent young researchers, these fellowships offer the fellows an opportunity to focus on a freely chosen research topic based on their own innovative ideas. Ultimately, the program works to foster and secure excellent researchers.

Eligibility: 1 . Be a citizen of a country that has diplomatic relations with Japan. 2. Candidates must have obtained their doctoral degree within six years of the date the fellowship goes into effect. 3. Universities and inter-university research institutes. 4. MEXT-affiliated institutions engaged in research. 5. Colleges of technology. 6. Institutions designated by the Minister of MEXT.

Level of Study: Postdoctorate

Type: Fellowship

Value: Up to $¥ 1.5$ million/year

Length of Study: 3 years

Frequency: Annual

For further information contact:

5-3-1 Kojimachi, Chiyoda-ku, Tokyo 102-0083, Japan.

Tel: $\quad$ (81) 332633444

Email: postdoc-standardjsps.go.jp

\section{Japanese American Citizens League (JACL)}

National Headquarters, 1765 Sutter Street, San Francisco, CA 94115, United States of America.

Tel: $\quad$ (1) 4153451075,4159215225

Email: ncwnp@jacl.org

Website: www.jacl.org

Contact: Scholarships Officer

The Japanese American Citizens League (JACL) was founded in 1929 to fight discrimination against people of 
Japanese ancestry. It is the largest and one of the oldest Asian American organizations in the USA. The JACL has over 24,500 members in 112 chapters located in 25 states, Washington, DC, and Japan. The organization operates within a structure of eight district councils, with headquarters in San Francisco, CA.

\section{Mike M. Masaoka Congressional Fellowship}

Purpose: To financially support and develop leaders for public service

Eligibility: Candidates must be U.S. citizens who are graduating college seniors or students in graduate or professional programs and a member of the JACL. Preference will be given to those who have demonstrated a commitment to Asian American issues, particularly those affecting the Japanese American community. Communication skills, especially in writing, are important

Level of Study: Postgraduate, Professional development Type: Fellowship

Value: US\$2,200 to US\$2,500 a month

Length of Study: 1 year

Frequency: Annual

Country of Study: United States of America

Application Procedure: Applicants must send a completed application form and a letter of reference to the JACL national headquarters

Closing Date: May

Funding: Foundation

Additional Information: Preference will be given to those who have demonstrated a commitment to Asian American issues, particularly those affecting the Japanese American community. Please see the website for further details at www.jacl.org/now-accepting-applications-for-mike-m-masaokacongressional-fellowship/ jacl.org/about/jobs-at-jacl/mike-mmasaoka-congressional-fellowship/

\section{For further information contact:}

Japanese American Citizens League Headquarters, Mike M. Masaoka Fellowship, 1850 M Street NW, Suite 1100, Washington, DC 20036, United States of America.

Email: policy@jacl.org

\section{Norman Y. Mineta Fellowship}

Purpose: To focus on public policy advocacy as well as programs of safety awareness in the Asian Pacific American (APA) community
Eligibility: Open to the members of the JACL with 4-year degree from an accredited college or university having excellent writing, analytical, and computer skills

Level of Study: Postgraduate

Type: Fellowship

Value: US\$2,500 a month

Length of Study: 12 months

Application Procedure: Interested applicants should submit a curriculum vitae, a sample of writing, and names and contact information for two references to the Washington, DC office of the JACL at policy@jacl.org with 'Mineta Fellowship' in the subject line

Closing Date: 18 May

Contributor: State Farm Insurance

Additional Information: Candidates must have ability to take directions and follow through with assignments, must work well with others, and have good interpersonal skills. Please see the website for further details www.jacl.org/internships-andfellowships/ jacl.org/internships-and-fellowships/

\section{For further information contact:}

JACL, 1828 L Street, NW Suite 802, Washington, DC 20036, United States of America.

$\begin{array}{ll}\text { Tel: } & \text { (1) } 2022231240 \\ \text { Fax: } & \text { (1) } 2022968082 \\ \text { Email: } & \text { dc@jacl.org }\end{array}$

\section{Jiamusi University}

\section{Heilongjiang Provincial Government Scholarships}

Purpose: the Jiamusi is the provincial key construction university with high level in Heilongjiang province, which is also a comprehensive university with a wide range of categories and medical specialties

Eligibility: For a Bachelors's degree, the candidate should have a high school degree with good marks/percentages.Also for a master's degree, you need to have a bachelor's degree with excellent grades. Similarly for PhD applicant needs a masters degree as well as an excellent percentage.

Level of Study: Postgraduate

Type: Scholarship

Frequency: Annual

Country of Study: Any country

Closing Date: 30 April

Funding: International office

Additional Information: www.china-admissions.com/ chinese-scholarships/heilongjiang-government-scholarshipinternational-students/ 


\section{For further information contact:}

Room No. 209, the Admission Office of International Education College of Jiamusi University, No. 258 Xuefu Street, Jiamusi City, Heilongjiang Province, China.

Tel: $\quad$ (86) 4548603918

Fax: (86) 4548603918

Email: jmsuadmission@163.com

\section{John Carter Brown Library at Brown University}

Box 1894, Brown University, Providence, RI 02912, United States of America.

Tel: $\quad$ (1) 4018632725

Email: JCBL_Information@Brown.edu

Website: www.jcbl.org

The John Carter Brown Library, an independently funded and administered institution for advanced research in history and the humanities, is located on the campus of Brown University. The Library supports research focused on the colonial history of the Americas, including all aspects of the European, African, and Native American involvement.

\section{Library Associates Fellowship}

Purpose: The Hodson Trust - John Carter Brown Library Fellowship supports work by academics, independent scholars and writers working on significant projects relating to the literature, history, culture

Type: Fellowship

Value: The stipend is US $\$ 5,000$ per month for a total of US $\$ 20,000$

Length of Study: 2 Month

Frequency: Annual

Closing Date: 15 March

Additional Information: For more information on the fellowships and the sponsor institutions, please visit starrcenter. washcoll.edu and www.brown.edu/Facilities/John_Carter_ Brown_Library. jcblibrary.org/fellowships/apply

\section{For further information contact:}

Email: jjohnson24@washcoll.edu OR applications starrcenter@washcoll.edu

\section{Norman Fiering Fund}

Purpose: To support scholars in any area of research related to the Library's holdings

Eligibility: Open to scholars in any area of research related to the Library's holdings

Type: Funding support

Value: US\$2,100 per month

Length of Study: $2-4$ months

Country of Study: United States of America

Closing Date: 3 January

\section{For further information contact:}

John Carter Brown Library, Box 1894, Providence, RI 02912, United States of America.

Email: JCBL_Fellowships@Brown.edu

\section{Ruth and Lincoln Ekstrom Fellowship}

Purpose: To sponsor historical research

Eligibility: Open to scholars engaged in predoctoral, postdoctoral or independent research. Graduate students must have passed their preliminary or general examinations at the time of application

Level of Study: Postdoctorate, Predoctorate, Research

Type: Fellowship

Value: US $\$ 2,100$ per month

Length of Study: 2-4 months

Frequency: Annual

Country of Study: United States of America

Application Procedure: Applicants must complete an application form. Candidates should write to, or email the Director

Closing Date: 15 December

Funding: Private

No. of awards given last year: 1

\section{John E Fogarty International Center (FIC) for Advanced Study in the Health Sciences}

Building 31, 31 Center Drive, MSC 2220, Bethesda, MD 20892-2220, United States of America.

Tel: $\quad$ (1) 3014962075

Email: FICinfo@mail.nih.gov

Website: www.fic.nih.gov

Contact: Program Officer 
The John E Fogarty International Center (FIC) for Advanced Study in the Health Sciences, a component of the National Institutes of Health $(\mathrm{NIH})$, promotes international co-operation in the biomedical and behavioural sciences. This is accomplished primarily through long- and short-term fellowships, small grants and training grants. This compendium of international opportunities is prepared by the FIC with the hope that it will stimulate scientists to seek research enhancing experiences abroad.

\section{Global Health Research Initiative Program for New Foreign Investigators (GRIP)}

Purpose: To assist well-trained young investigators to contribute to health care advances in their home countries

Eligibility: Open to all well-trained young investigators. To verify eligibility, new foreign investigators should review the answers to Frequently Asked Questions. Please contact Dr Xingzhu Liu by email at xingzhu.liu@nih.gov with questions Level of Study: Postgraduate

Type: Grant

Value: US\$50,000 per year

Length of Study: 5 years

Frequency: Annual

Application Procedure: Application form on request

Funding: Foundation

Contributor: Fugarty International Center

Additional Information: Please see the website for further details www.fic.nih.gov/programs/Pages/new-foreign-invest igators.aspx www.fic.nih.gov/Programs/Info/Pages/grip-faqs. aspx

\section{For further information contact:}

Email: butrumb@mail.nih.gov

\section{John E Fogarty Foreign Funded Fellowship Programs}

Purpose: To allow United States scientists to conduct collaborative research abroad

Eligibility: Open to scientists who are United States citizens or permanent residents invited by foreign host scientists to participate in research projects of mutual interest

Level of Study: Postdoctorate

Type: Fellowship

Value: To cover the visiting scientist's individual expenses abroad

Length of Study: Usually up to 1 year, possible extension in some countries

Frequency: Annual
Country of Study: Other

Application Procedure: Applicants must complete an application form, available on request or downloadable from www. avh.de

Closing Date: 5 December

Additional Information: Because fellowships are intended to support an individual's expenses abroad, the foreign host is expected to have the resources to support the research project. Types of activities in which Fellows engage include collaboration in basic or clinical research and familiarisation with or utilisation of special techniques and equipment not otherwise available to the applicant. The programmes do not provide support for activities which have as their principal purpose conducting brief observational visits, attending scientific meetings or formal training courses, or providing full-time clinical, technical or teaching services. Funding is provided by the Alexander von Humboldt Foundation (Germany), the Israeli Ministry of Health, the Japan Society for the Promotion of Science, the Japan Science and Technology Agency, the Swedish Medical Research Council, and the National Science Council of Taiwan. Candidates may apply to only one of these programmes during any given year

\section{For further information contact:}

Alexander von Humboldt Foundation, US Liaison Office, 1055 Thomas Jefferson Street NW, Suite 2030, Washington, DC 20007, United States of America.
Tel:
(1) 2022962990
Fax: (1) 2028338514
Email: info@humboldtfoundation.org

\section{John F. Kennedy Library Foundation}

Columbia Point, Boston, MA 02125, United States of America.

Tel: $\quad$ (1) 8665141960

Email: Kennedy.library@nara.gov

Website: www.jfklibrary.org

Contact: Fellowships Administrator

The John F. Kennedy Library Foundation is a non-profit organization that provides financial support, staffing and creative resources for the John F. Kennedy Presidential Library and Museum whose purpose is to advance the study and understanding of President Kennedy's life and career, and the times in which he lived and to promote a greater appreciation of America's political and cultural heritage, the process of governing and the importance of public service. 


\section{Abba P. Schwartz Research Fellowship}

Purpose: It is intended to support a scholar in the production of a substantial work in the areas of immigration, naturalization, or refugee policy, subjects of great personal and professional interest to Mr Schwartz

Eligibility: See award purpose

Level of Study: Postgraduate

Type: Fellowship

Value: A stipend of up to US $\$ 3,100$

Frequency: Annual

Country of Study: United States of America

Application Procedure: Please submit the following documentation: (1) an application form (pdf) accompanied by a brief proposal (three to four pages) in the form of a letter describing the planned research, its significance, the intended audience, and expected outcome; (2) two letters of recommendation from academic or other appropriate references; (3) a sample of your writing (approx. 10 pages); (4) a project budget; and (5) a CV

Closing Date: 30 September

Funding: Foundation

Contributor: John F. Kennedy Library Foundation

Additional Information: The estimated per diem cost of accommodations, meals, and incidentals for Boston is US $\$ 250$ Please see the website for further details www. jfklibrary.org/archives/research-fellowships-grants/schwartzfellowship

\section{For further information contact:}

Tel: $\quad$ (1) 6175141630

Fax: (1) 6175141625

Email: Kennedy.Fellowships@nara.gov

\section{Arthur M. Schlesinger, Jr. Fellowship}

Purpose: To financially support scholars in the production of substantial work on the foreign policy of the Kennedy years Eligibility: Open to citizens of the US only

Level of Study: Postgraduate

Type: Fellowships

Value: Up to US\$5,000

Frequency: Annual

Country of Study: United States of America

Application Procedure: Applicants must submit application form, financial need analysis, essay, reference letters, and curriculum vitae. Applicants are strongly encouraged to contact the Kennedy Library for information about its collections and holdings before applying

Closing Date: 15 August

Funding: Foundation
Contributor: Schlesinger Fund

Additional Information: Proposals are invited from all sources, but preference will be given to applicants specializing in the work on the foreign policy of the Kennedy years especially with regard to the western hemisphere, or on Kennedy domestic policy, especially with regard to racial justice and to the conservation of natural resources. Preference is also given to projects not supported by large grants from other institutions. Please see the website for further details www. jfklibrary.org/archives/research-fellowships-grants/schlesingerfellowship

\section{For further information contact:}

Tel: (1) 6175141629

Fax: (1) 6175141625

\section{John R. Mott Scholarship Foundation}

\section{John R. Mott Scholarship}

Purpose: This award is for Italian students from the Calabria region attending college. Awards are given based on academic achievement and financial need

Eligibility: 1. Students native to the region of Calabria, Italy. 2. Students enrolled and who will be attending university or graduate school in Fall 2020. 3. Students seeking an education leading to a degree or professional certification.

Level of Study: Graduate

Type: Scholarship

Value: US $\$ 10,000$

Frequency: Annual

Country of Study: United States of America

Application Procedure: Applications are accepted between 9 February and 15 April. Applications will be available online from the John R. Mott Scholarship Foundation website. Applicants must complete the application online, and mail or fax the following materials to the foundation by the deadline: official transcript from university or official completion certification and academic performance document from high school, and ISEE-U certification attesting to the tax liability of the family

Funding: Foundation

Additional Information: mottscholarship.org/index.asp

\section{For further information contact:}

1860 19th St., N.W. Washington, DC 20009, United States of America.

Tel: $\quad$ (1) 2024832618

Email: scholarships@swe.org 


\section{Johns Hopkins University}

615 N. Wolfe Street, Suite E1002, Baltimore, MD 21205, United States of America.

Tel: $\quad$ (1) 4105163400,4109551680

Email: admiss@jhsph.edu

Website: webapps.jhu.edu/jhuniverse/information_about_ hopkins/

Contact: Grants Co-ordinator

The vision of the Johns Hopkins Center for Alternatives to Animal Testing is to be a leading force in the development and use of reduction, refinement and replacement alternatives in research, testing and education to protect and enhance the health of the public.

\section{Center for Alternatives to Animal Testing Grants Programme}

Purpose: To promote and support research in the development of in vitro and other alternative techniques

Eligibility: No eligibility restrictions. Applicants' proposals must meet the goals of the CAAT Grants Program

Level of Study: Unrestricted

Value: For proposals relating to toxicology: up to US\$25,000; proposals relating to developmental immunotoxicology: up to US\$50,000

Length of Study: 1 year

Frequency: Annual

Country of Study: United States of America

Application Procedure: Applicants must complete a preproposal. After review, selected applicants are invited to submit a full application

No. of awards offered: 30

Closing Date: 21 March

Funding: Private

No. of awards given last year: 12

No. of applicants last year: 30

Additional Information: Please see the website for further details caat.jhsph.edu/programs/grants/

\section{For further information contact:}

615 N Wolfe St W7032, Baltimore, MD 21205, United States of America.

Fax: (1) 4106142871

Email: caat@jhsph.edu

\section{Greenwall Fellowship Program}

Purpose: To provide an unparalleled opportunity for fellowship and faculty development training in bioethics and health policy

Eligibility: Open to applicants who have Doctoral degrees in medicine, nursing, philosophy, law, public health, biomedical sciences, social sciences or a related field

Level of Study: Postdoctorate

Type: Fellowship

Value: US\$122,003

Length of Study: 2 years

Frequency: Annual

Study Establishment: Johns Hopkins University

Country of Study: United States of America

Application Procedure: Applicants must send a cover letter, a personal statement describing why they want to be a Greenwall Fellow, a copy of their curriculum vitae, 3 reference letters, official copies of undergraduate and graduate/ professional school transcripts and copies of their written and/or published work

Closing Date: 1 December

For further information contact:

Email: fellows@ihsph.edu

\section{Joint Institute for Laboratory Astrophysics (formerly Joint Institute for Laboratory Astrophysics)}

440 B, University of Colorado, Boulder, CO 80309, United States of America.

Tel: $\quad$ (1) 3034927789

Email: $\quad$ jilavf@jila.colorado.edu

Website: www.colorado.edu

Contact: Programme Assistant

JILA's interests are at present research and applications in the fields of laser technology, optoelectronics, precision measurement, surface science and semiconductors, information and image processing, and materials and process science, as well as basic research in atomic, molecular and optical physics, precision measurement, gravitational physics, chemical physics, astrophysics and geophysical measurements. To provide an opportunity for persons actively contributing to these fields, JILA operates the Visiting Fellowship Programme as well as the Postdoctoral Research Associate Programme. 


\section{Joint Institute for Laboratory Astrophysics Postdoctoral Research Associateship and Visiting Fellowships}

Purpose: To support additional training beyond the $\mathrm{PhD}$ and sabbatical research

Eligibility: There are no restrictions other than those that might be required by the grant that supports the research

Level of Study: Postdoctorate, Professional development Type: Fellowship

Value: Varies

Length of Study: Visiting fellowships are for 4-12 months and Postdoctoral Research Associateships are for 1 year or more

Frequency: Annual

Country of Study: United States of America

Application Procedure: Applicants should download an application form, complete it, and send it (along with requested supporting materials) to the Visiting Scientists Program Assistant. All materials may be submitted via email to secretary via email

Closing Date: 1 November

Funding: Government

Contributor: Varies

Additional Information: Please see the website for further details jila.colorado.edu/students-postdocs/postdocs

\section{For further information contact:}

Visiting Scientists Program, 440 UCB, Boulder, CO 80309, United States of America.

Tel: $\quad$ (1) 3034925749

Email: secretary@jila.colorado.edu

\section{Juvenile Diabetes Foundation International/The Diabetes Research Foundation}

26 Broadway, 14th Floor, New York, NY 10004, United States of America.

Tel: (1) 1800533 CURE (2873)

Email: info@jdrf.org

Website: www.jdrf.org

Contact: Grant Administrator

JDRF remains dedicated to finding a cure for type 1 diabetes as our highest priority. In addition to focusing on specific research challenges and gaps that will lead to curing, better treating, and preventing type 1 diabetes. JDRF works to decrease barriers to commercial development of products for type 1 diabetes.

\section{Strategic Research Agreement}

Purpose: To support and fund research to find a cure for Type 1 diabetes

Eligibility: Required MD, DMD, DVM, PhD, or equivalent and faculty position or equivalent

Level of Study: Research

Type: Grant

Value: Varies

Length of Study: 3 years

Closing Date: 1 February

Additional Information: Please check website for further details

\section{Juvenile Diabetes Research Foundation - JDRF}

Starting in the US in 1970, JDRF began in Australia in 1982 as a small group of parents who believed their children deserved better. Now, millions of people work with and support JDRF in over 20 countries. We connect the best people in every discipline, industry and organisation with a single focus on destroying T1D. 40 years of investment in the best researchers has created an exciting pipeline from academic research through to clinical trials and therapies requiring approval and financial support for people to access them.

Tel:

(61) 290206100

Email: travelgrants@jdrf.org.au

Website: jdrf.org.au/

Contact: Grants Administration Officer on travelgrants@jdrf.org.au or 0290206139.

JDRF has transformed the understanding of Type 1 Diabetes (T1D). We have been part of every breakthrough in T1D care in the last 40 years. We drive innovation, demand action and stand with everyone facing life with T1D. We know research is the key to destroy T1D.

\section{JDRF PhD Top-up Scholarships 2020}

Purpose: The JDRF PhD Top-up scholarship is designed to support and encourage $\mathrm{PhD}$ students pursuing research in the 
field of type 1 diabetes in line with JDRF's mission - to treat, prevent and cure type 1 diabetes and its complications. The Top-Up will provide successful candidates with additional funding up to AU\$6,000 per year, on top of their PhD Scholarship stipend, full-time or part-time, contingent on satisfactory progress.

Eligibility: The JDRF PhD Top-Up scholarship is available to domestic students in receipt of a Research Training Program Stipend (formerly Australian Postgraduate Award), NHMRC Postgraduate Award or University-funded scholarship. Students must be pursuing research relevant to JDRF's mission to cure, treat and prevent type 1 diabetes and its complications. Applicants must be 1. Recipients of either a Research Training Program Stipend, NHMRC Postgraduate Award or a University-funded $\mathrm{PhD}$ scholarship 2. Not in receipt of any other $\mathrm{PhD}$ top-up funding 3. Pursuing research relevant to type 1 diabetes and its complications 4 . Australian citizens or permanent residents currently residing in Australia

Level of Study: Postgraduate

Type: Scholarship

Value: The Top-Up will provide successful candidates with additional funding up to AU\$6,000 per year, on top of their PhD Scholarship stipend, full-time or part-time, contingent on satisfactory progress.

Frequency: Annual

Country of Study: Australia

Application Procedure: The cut-off date for consideration of this scholarship is 5:00pm AEDT, 20th April. Applications must be submitted on the following application form with headings in order: 1. Details Summary - Please complete all fields within the application form. 2. Applicant Summary Please complete all fields within the application form and adhere to the word limits of each question. 3. Letter confirming offer of a PhD Scholarship - Include a letter confirming your offer of a Research Training Program Stipend, NHMRC Postgraduate Award or a University-funded PhD scholarship. This should be pasted into the document. 4. Curriculum Vitae - 4 page limit. Please limit all information provided to that requested within the application form. 5. Academic transcript - Please provide a certified copy of your academic transcript. This should be pasted into the document. 6. NB: Please note that acceptable persons who may certify a document are listed in Schedule 2 of the 'Statutory Declarations Regulations 2018' located here. 7. Certification of both the Applicant and their Institution's Research Administration Office. 8. NB: Electronic signatures are acceptable. Letters of Recommendation - In addition to the above, two letters of recommendation must be sent by referees before 5:00pm AEDT, 20th April, directly to travelgrants@jdrf.org. au. Letters of recommendation should be e-mailed directly by the referee to maintain confidentiality. It is the applicant's responsibility to ensure that these letters are sent on time.

Closing Date: 20 April

\section{For further information contact:}

Applications are to be submitted by your Institution's Research Administration Office as one document in PDF format with the naming convention of: "Surname_Firstname_Top-up.pdf" to travelgrants@jdrf.org.au. 